\title{
Effect of Rooting Media and IBA Treatments on Shoot Production and Survival of Terminal Cuttings in Guava (Psidium guajava L.) cv. Taiwan Pink
}

\author{
T. Dhatrika Rani*, D. Srihari, A.V.D. Dorajeerao and P. Subbaramamma \\ Department of Fruit science, Dr. YSR Horticultural University, \\ Venkataramannagudem - 534101, Andhra Pradesh, India \\ *Corresponding author
}

\section{A B S T R A C T}

\begin{tabular}{|l|}
\hline Ke y w or d s \\
Rooting media, IBA, \\
Terminal cuttings, Guava \\
\hline Article Info \\
\hline Accepted: \\
04 October 2018 \\
Available Online: \\
10 November 2018 \\
\hline
\end{tabular}

\section{Introduction}

Guava (Psidium guajava L.), the "Poor man's fruit" or "Apple of the tropics" belongs to tropical and subtropical climate. It is native to the Tropical America stretching from Mexico to Peru. Guava belongs to Class: Magnoliopsida, Sub-class: Rosidae, Order: Myrtales, Family: Myrtaceae, Genus: Psidium, Scientific Name: Psidium guajava L. The genus Psidium contains 150 species, most of which are fruit bearing trees. The basic chromosomal number of guava is 11 . Most of the cultivars are diploid $(2 n=22)$, but some are natural and artificial triploids $(2 n=33)$, these are generally produce seedless fruits (Jaiswal and Nasim, 1992). In India, guava position in
The purpose of this study was to evaluate the effect of rooting media and Indole-3-butyric acid treatments on guava terminal cuttings cv Taiwan pink. The treatments comprised of three types of rooting media i.e., coco peat, vermiculite and saw dust and six concentrations of Indole-3-butyric acid i.e., $250 \mathrm{ppm}, 500 \mathrm{ppm}, 750 \mathrm{ppm}$ in solution form and $1500 \mathrm{ppm}, 3000 \mathrm{ppm}$ and $6000 \mathrm{ppm}$ in powdered form. The more favourable results were obtained from coco peat among the all 3 different rooting media and among the IBA treatments, $3000 \mathrm{ppm}$ recorded the best values in percentage of rooted cuttings, dry weight shoots per cutting, number of leaves per cutting, leaf area per cutting, total leaf chlorophyll content and survival percentage of rooted cuttings. production is fifth after Banana, Mango, Citrus and Papaya (NHB, 2015). It has attained a respectable place and popularity amongst the dietary list of common people in our country owing to nutritious, deliciousness, pleasing flavour and availability for a longer period of time during the year at moderate price.

It has great demand as a table fruit and as a raw material for the processing industries, leads to earn good foreign exchange (Purseglove, 1977).

Guava is hardy, drought tolerant, high yield potential and diverse use of fruits also helps in developing a good ecological system in 
addition to improve the rural economy as well as nutritional standard to a greater extent (Rathore, 2001). Besides its high nutritive value, it bears heavy crop every year and gives handsome economic returns (Singh et al., 2000). This has prompted the several farmers to take up guava cultivation on a commercial scale. It has been in cultivation since early $17^{\text {th }}$ century and gradually became a crop of commercial significance.

The main reasons for its popularity are prolific bearing nature and remunerative yields even without much care justifying its name as Poor man's apple. In Andhra Pradesh, guava is cultivated in an area of 6.2 thousand hectares with a production of 1 lakh tonnes and productivity of 16.27 tonnes per ha (NHB, 2015). In Andhra Pradesh, it is mostly grown in East Godavari, West Godavari, Guntur, Krishna, Ananthapuramu and Prakasam districts.

Guava is propagated commercially by means of both vegetative and direct seedling methods, but the fruits of commercial grade can be obtained only when plants are propagated through vegetative progeny. Vegetative propagation of guava can be done by budding (Gupta and Malhotra, 1985; Kaundal et al., 1987), air layering (Manna et al., 2004), stooling (Pathak and Saroj, 1988) and inarching (Mukherjee and Majumdar, 1983). In direct seedling method, progeny are not uniform due to segregation and recombination of different characters. Moreover, the plants propagated through seeds come to bearing much later than the plants propagated through cuttings. Clonal propagation of guava is the possible approach to ascertain uniformity among the progeny and to maintain good quality fruits (Giri et al., 2004). Initially, true-to-type planting material is a basic need in guava orchards to ensure both quality and quantity of guava fruits (Singh et al., 2005).
Propagation through air layering in guava is a time consuming and hence necessitated a search for alternate but effective means of vegetative propagation. Of late, several woody perennials are successfully and rapidly propagated through use of terminal cuttings. In this context, rapid methods of propagation become very important when planting material is limited due to scarcity of a clone or varieties or due to sudden expansion in acreage. Thus it leads to an idea about the utilization of terminal cuttings, rapid propagation method in guava.

\section{Materials and Methods}

An experiment was conducted on the effect of rooting media and IBA treatments on the root and shoot parameters of guava cv. Taiwan Pink at Kadiyaddha village, under the supervision of College of Horticulture, Dr. Y.S.R. Horticultural University, Venkataramannagudem, West Godavari District, Andhra Pradesh. The experiment was laid out in factorial completely randomized design with two factors viz., Rooting media (3 levels) and IBA treatments (6 levels), making eighteen treatment combinations which were replicated twice.

Terminal cuttings were planted in protrays consisting of rooting media viz., coco peat, vermiculite and saw dust after treating with IBA at 250, 500, $750 \mathrm{ppm}$ in solution form for 5 minutes and 1500, 3000, $6000 \mathrm{ppm}$ in powder form.

The terminal cuttings were kept under mist chamber for 35 days, under shade net for 10 days and after that, the rooted terminal cuttings were planted in $8 \times 10$ inches polybag with potting mixture consisting of Red soil and FYM in 2:1 proportion and kept under open conditions, the observations on various parameters at 135 DAP were recorded as presented below. 


\section{Results and Discussion}

\section{Percentage of rooted cuttings (\%)}

Significant differences were observed among the rooting media, IBA treatments as well as their interactions on percentage of rooted cuttings in terminal cuttings of guava cv. Taiwan Pink at 45 days after planting, the terminal cuttings planted in coco peat were found to record maximum percentage of rooting (73.98\%), followed by the vermiculite (70.51\%) and minimum percentage of rooting was observed in the terminal cuttings planted in saw dust medium (65.98\%) (Table 1).

Among the IBA treatments, IBA powder dip @ $3000 \mathrm{ppm}$ performed the best with 79.81 percentage of rooted cuttings and was followed by IBA powder dip @ 6000 ppm (76.19\%) while the minimum percentage of rooting $(60.13 \%)$ was observed with solution dip of IBA@ 950 ppm.

There existed a significant interaction between rooting media and IBA treatments for percentage of rooted cuttings. Significantly highest percentage of rooting $(85.19 \%)$ was recorded by the terminal cuttings planted in coco peat + dipping in IBA powder @ 3000 ppm $\left(\mathrm{M}_{1} \mathrm{G}_{5}\right)$.

Among the three rooting media, terminal cuttings planted in coco peat medium recorded the maximum percentage of rooting which might be perhaps due to the release of phenolic compounds from the coir pith (Lokesha et al., 1988) and also can be attributed to the beneficial physical characteristics of coir pith (Smith, 1995) like aeration and water holding capacity. Presence of leaves on cuttings also could have played an important role in the initiation of roots in many plant species. Leaves considerably influence the rooting of cuttings because of their ability to produce endogenous auxins, carbohydrates by means of photosynthesis (Newton et al., 1992). Krieken et al., (1993) reported that IBA might have enhanced the rooting by increase of internal Auxins, or synergistically modify the action of IAA or due to synthesis of endogenous IAA. Treatment of cuttings with increasing concentrations of IBA coupled with endogenous auxins already present in the cuttings could improve the percentage of rooting in cuttings as reported by Melgarejo $e t$ al., (2000).

The present results were in harmony with the findings of Mayer et al., (2015) who recorded higher percentage of rooted cuttings in 3000 ppm of IBA than in $6000 \mathrm{ppm}$ in softwood cuttings of peach under intermittent mist system. The results are in line with Malik et al., (2013) in softwood cuttings of guava. Such observations were also made by Abdul $e t$ al., (2013) in guava.

According to Habibi, (2010) the increase in auxin concentrations led to increase in oleander plant rooting (Nerium oleander L.) up to $3000 \mathrm{ppm}$ of IBA and subsequent increase in IBA was found to decrease in plant rooting. Shadparvar et al., (2011) stated that plants should be contained a certain quantity of IBA for successful induction of rooting primordia. The application of IBA might had an indirect influence by enhancing the speed of transformation of rooting primordia and movement of sugars to the base of cuttings and consequently formation of young and active roots.

\section{Dry weight of shoots per cutting (g)}

The dry weight of shoots at 135 DAP significantly varied due to rooting media, IBA treatments as well as their interactions. The terminal cuttings planted in coco peat medium recorded significantly maximum dry weight $(4.50 \mathrm{~g})$ followed by those terminal cuttings 
planted in vermiculite (4.30 g). Minimum dry weight of shoot was obtained in terminal cuttings planted in sawdust $(3.92 \mathrm{~g})$. Application of IBA powder at a concentration of $3000 \mathrm{ppm}$ performed the best with the highest dry weight of shoots $(4.75 \mathrm{~g})$ followed by those treated with IBA powder @ 6000 ppm (4.58 g) while the minimum shoot dry weight (3.63 g) was observed in solution dip with IBA at $750 \mathrm{ppm}$. These results are in accordance with Thayamini (2015) in dragon fruit (Table 2).

There was a significant interaction between rooting media and IBA treatments for maximum dry weight of shoots. Significantly maximum dry weight of shoots $(5.10 \mathrm{~g})$ was found in terminal cuttings planted in coco peat medium + treatment with IBA 3000 ppm $\left(\mathrm{M}_{1} \mathrm{G}_{5}\right)$.

Among the rooting media, terminal cuttings planted in coco peat recorded the maximum dry weight of shoot. It could be attributed due to increase in number of leaves, length and number of shoots per cutting. Among IBA treatments, IBA powder dip @ 3000 ppm performed the best. This might be due to the reason that auxins activated shoot growth could have elongated the stems and leaves through cell division accounting for a higher dry weight of shoot (Abraham, 1996). The promoting effect of IBA on shoot parameters can be attributed to the reason that the better rooting coupled with a better leaf growth might have led to a higher shoot sprouts and supported their development (Paul and Aditi, 2009). As discussed earlier IBA at 3000 ppm concentration favoured many shoot parameters in positive direction and at the same time sustained the root strength to continue the vigour and vitality in taking up the nutrients as well as moisture from the growing media. The integrated effect over root and shoot parameters established the merit of IBA powder dip@ 3000 ppm concentration.

\section{Number of leaves per cutting}

At 135 DAP, terminal cuttings planted in coco peat medium showed significantly maximum number of leaves (24.21) followed by the terminal cuttings planted in vermiculite (20.95), while the minimum number of leaves (16.56) was observed in the terminal cuttings planted in saw dust. The maximum number of leaves per cutting was found in the terminal cuttings treated with IBA powder @ 3000 ppm (25.40) which was followed by terminal cuttings treated with $6000 \mathrm{ppm}$ of IBA concentration (23.51), while the lowest number of leaves (16.33) was observed in terminal cuttings treated with solution dip with IBA@ 950 ppm (Table 3).

There existed a significant interaction between rooting media and IBA treatments for the number of leaves per cutting. Significantly maximum number of leaves per cutting (30.14) was found in terminal cuttings planted in coco peat medium + treatment with IBA powder@3000 ppm $\left(\mathrm{M}_{1} \mathrm{G}_{5}\right)$. The maximum number of leaves per cutting was produced in terminal cuttings planted in coco peat, which might be due to superior root development in this medium. It could be in turn attributed to the higher moisture retention capacity, porosity and nutrient status of coir pith (Nagarajan et al., 1985) as proven in coco peat medium. Maximum number of leaves was produced in cuttings treated with IBA 3000 ppm which might be due to activation of shoot growth leading to an increased number of nodes that leads to development of more number of leaves. The increase in number of leaves per cutting might be due to the reason that the plant might diverted maximum assimilate quantities to the leaf buds, since the leaves are one of the production sites of natural auxins in them besides being very important for vital processes like photosynthesis and respiration (Wahab et al., 2001). 
Table.1 Effect of rooting media and IBA treatments on percentage of rooted cuttings (\%) of terminal cuttings in guava cv. Taiwan Pink at 45 DAP

\begin{tabular}{|c|c|c|c|c|}
\hline \multirow{3}{*}{$\begin{array}{c}\text { IBA } \\
\text { treatments } \\
(\mathbf{G})\end{array}$} & \multicolumn{3}{|c|}{ Percentage of rooted cuttings $(\%)$} & \multirow[t]{3}{*}{ Mean } \\
\hline & \multicolumn{3}{|c|}{ Rooting media (M) } & \\
\hline & Coco peat $\left(M_{1}\right)$ & $\begin{array}{c}\text { Vermiculite } \\
\left(\mathbf{M}_{2}\right)\end{array}$ & $\begin{array}{c}\text { Saw dust } \\
\left(\mathbf{M}_{3}\right)\end{array}$ & \\
\hline $250 \mathrm{ppm}\left(\mathrm{G}_{1}\right)$ & $71.06(57.43)$ & $68.94(56.11)$ & $64.72(53.54)$ & $68.24(55.69)$ \\
\hline 500 ppm $\left(G_{2}\right)$ & $67.52(55.23)$ & $65.00(53.70)$ & $61.30(51.51)$ & $64.60(53.48)$ \\
\hline 750 ppm $\left(\mathbf{G}_{3}\right)$ & $62.68(52.32)$ & $62.02(51.93)$ & $55.71(48.26)$ & $60.13(50.84)$ \\
\hline $1500 \mathrm{ppm}\left(\mathrm{G}_{4}\right)$ & $75.89(60.57)$ & $71.91(57.97)$ & $68.09(55.58)$ & $71.96(58.04)$ \\
\hline 3000 ppm $\left(G_{5}\right)$ & $85.19(67.35)$ & $79.85(63.30)$ & $74.40(59.58)$ & $79.81(63.41)$ \\
\hline $6000 \mathrm{ppm}\left(\mathrm{G}_{6}\right)$ & $81.53(64.53)$ & $75.37(60.22)$ & $71.69(57.83)$ & $76.19(60.86)$ \\
\hline Mean & $73.98(59.57)$ & $70.51(57.21)$ & $65.98(54.38)$ & $70.15(57.05)$ \\
\hline Factor & M & G & \multicolumn{2}{|c|}{$M \times G$} \\
\hline $\begin{array}{c}\text { S Em } \pm \\
\text { CD at } 5 \%\end{array}$ & $\begin{array}{l}0.19 \\
0.57\end{array}$ & $\begin{array}{l}0.27 \\
0.80\end{array}$ & \multicolumn{2}{|c|}{$\begin{array}{l}0.47 \\
1.39\end{array}$} \\
\hline
\end{tabular}

$\mathrm{G}_{1}, \mathrm{G}_{2}$ and $\mathrm{G}_{3}$ are treatments of guava terminal cuttings with IBA in solution form.

$\mathrm{G}_{4}, \mathrm{G}_{5}$ and $\mathrm{G}_{6}$ are treatments of guava terminal cuttings with IBA in powder form.

* Figures in parenthesis indicate transformed values.

Table.2 Effect of rooting media and IBA treatments on dry weight of shoots per cutting (g) of terminal cuttings in guava cv. Taiwan Pink at 135 DAP

\begin{tabular}{|c|c|c|c|c|}
\hline \multirow{3}{*}{$\begin{array}{c}\text { IBA } \\
\text { treatments } \\
(\mathbf{G})\end{array}$} & \multicolumn{3}{|c|}{ Dry weight of shoots per cutting(g) } & \multirow[t]{3}{*}{ Mean } \\
\hline & \multicolumn{3}{|c|}{ Rooting media (M) } & \\
\hline & $\begin{array}{c}\text { Coco peat } \\
\left(\mathbf{M}_{1}\right)\end{array}$ & $\begin{array}{l}\text { Vermiculite } \\
\qquad\left(\mathbf{M}_{2}\right)\end{array}$ & $\begin{array}{c}\text { Saw dust } \\
\left(\mathbf{M}_{3}\right)\end{array}$ & \\
\hline $250 \mathrm{ppm}\left(\mathrm{G}_{1}\right)$ & 4.36 & 4.24 & 3.83 & 4.14 \\
\hline $500 \mathrm{ppm}\left(\mathrm{G}_{2}\right)$ & 4.13 & 4.00 & 3.65 & 3.92 \\
\hline $750 \mathrm{ppm}\left(\mathrm{G}_{3}\right)$ & 3.81 & 3.65 & 3.43 & 3.63 \\
\hline $1500 \mathrm{ppm}\left(\mathrm{G}_{4}\right)$ & 4.77 & 4.47 & 4.09 & 4.44 \\
\hline 3000 ppm $\left(G_{5}\right)$ & 5.10 & 4.84 & 4.32 & 4.75 \\
\hline $6000 \mathrm{ppm}\left(\mathrm{G}_{6}\right)$ & 4.87 & 4.64 & 4.22 & 4.58 \\
\hline Mean & 4.50 & 4.30 & 3.92 & 4.24 \\
\hline Factor & M & $\mathrm{G}$ & \multicolumn{2}{|c|}{$M \times G$} \\
\hline $\begin{array}{c}\text { S Em } \pm \\
\text { CD at } 5 \%\end{array}$ & $\begin{array}{l}0.01 \\
0.02\end{array}$ & $\begin{array}{l}0.01 \\
0.02\end{array}$ & \multicolumn{2}{|c|}{$\begin{array}{l}0.01 \\
0.04\end{array}$} \\
\hline
\end{tabular}

$\mathrm{G}_{1}, \mathrm{G}_{2}$ and $\mathrm{G}_{3}$ are treatments of guava terminal cuttings with IBA in solution form. $\mathrm{G}_{4}, \mathrm{G}_{5}$ and $\mathrm{G}_{6}$ are treatments of guava terminal cuttings with IBA in powder form. 
Table.3 Effect of rooting media and IBA treatments on number of leaves per cutting of terminal cuttings in guava cv. Taiwan Pink at 135 DAP

\begin{tabular}{|c|c|c|c|c|}
\hline \multirow{3}{*}{$\begin{array}{c}\text { IBA } \\
\text { treatments } \\
\text { (G) }\end{array}$} & \multicolumn{3}{|c|}{ Number of leaves per cutting } & \multirow[t]{3}{*}{ Mean } \\
\hline & \multicolumn{3}{|c|}{ Rooting media $(\mathrm{M})$} & \\
\hline & $\begin{array}{c}\text { Coco peat } \\
\left(\mathbf{M}_{1}\right)\end{array}$ & $\begin{array}{c}\text { Vermiculite } \\
\left(\mathbf{M}_{2}\right)\end{array}$ & $\begin{array}{c}\text { Saw dust } \\
\left(\mathbf{M}_{3}\right)\end{array}$ & \\
\hline $250 \mathrm{ppm}\left(\mathrm{G}_{1}\right)$ & 26.40 & 23.81 & 21.15 & 23.78 \\
\hline 500 ppm $\left(G_{2}\right)$ & 24.28 & 20.13 & 18.62 & 21.01 \\
\hline $750 \mathrm{ppm}\left(\mathrm{G}_{3}\right)$ & 21.39 & 19.65 & 17.47 & 19.50 \\
\hline 1500 ppm $\left(G_{4}\right)$ & 30.50 & 26.24 & 22.39 & 26.37 \\
\hline 3000 ppm $\left(G_{5}\right)$ & 33.77 & 30.22 & 25.39 & 29.79 \\
\hline 6000 ppm $\left(G_{6}\right)$ & 31.43 & 28.31 & 24.27 & 28.00 \\
\hline Mean & 27.96 & 24.72 & 21.55 & 24.74 \\
\hline Factor & M & G & \multicolumn{2}{|c|}{$M \times G$} \\
\hline S Em \pm & 0.115 & 0.163 & \multicolumn{2}{|c|}{$\begin{array}{l}0.282 \\
0.838\end{array}$} \\
\hline
\end{tabular}

$\mathrm{G}_{1}, \mathrm{G}_{2}$ and $\mathrm{G}_{3}$ are treatments of guava terminal cuttings with IBA in solution form.

$\mathrm{G}_{4}, \mathrm{G}_{5}$ and $\mathrm{G}_{6}$ are treatments of guava terminal cuttings with IBA in powder form.

Table.4 Effect of rooting media and IBA treatments on leaf area per cutting $\left(\mathrm{cm}^{2}\right)$ of terminal cuttings in guava cv. Taiwan Pink at 135 DAP

\begin{tabular}{|c|c|c|c|c|}
\hline \multirow{3}{*}{$\begin{array}{c}\text { IBA } \\
\text { treatments } \\
\text { (G) }\end{array}$} & \multicolumn{3}{|c|}{ Leaf area per cutting $\left(\mathrm{cm}^{2}\right)$} & \multirow[t]{3}{*}{ Mean } \\
\hline & \multicolumn{3}{|c|}{ Rooting media (M) } & \\
\hline & $\begin{array}{c}\text { Coco peat } \\
\left(M_{1}\right)\end{array}$ & $\begin{array}{c}\text { Vermiculite } \\
\left(\mathbf{M}_{2}\right)\end{array}$ & $\begin{array}{c}\text { Saw dust } \\
\left(M_{3}\right)\end{array}$ & \\
\hline $250 \mathrm{ppm}\left(\mathrm{G}_{1}\right)$ & 173.80 & 165.44 & 122.84 & 154.03 \\
\hline $500 \mathrm{ppm}\left(\mathrm{G}_{2}\right)$ & 162.24 & 147.36 & 117.96 & 142.52 \\
\hline $750 \mathrm{ppm}\left(\mathrm{G}_{3}\right)$ & 156.84 & 126.36 & 108.76 & 130.65 \\
\hline $1500 \mathrm{ppm}\left(\mathrm{G}_{4}\right)$ & 205.00 & 171.92 & 130.36 & 169.09 \\
\hline 3000 ppm $\left(\mathbf{G}_{5}\right)$ & 241.08 & 206.80 & 161.84 & 203.24 \\
\hline $6000 \mathrm{ppm}\left(\mathrm{G}_{6}\right)$ & 223.00 & 187.80 & 153.36 & 188.05 \\
\hline Mean & 193.66 & 167.61 & 132.52 & 164.60 \\
\hline Factor & M & G & & \\
\hline $\begin{array}{c}\text { S Em } \pm \\
\text { CD at 5\% }\end{array}$ & $\begin{array}{l}0.92 \\
2.74\end{array}$ & $\begin{array}{l}1.30 \\
3.87\end{array}$ & & \\
\hline
\end{tabular}

$\mathrm{G}_{1}, \mathrm{G}_{2}$ and $\mathrm{G}_{3}$ are treatments of guava terminal cuttings with IBA in solution form.

$\mathrm{G}_{4}, \mathrm{G}_{5}$ and $\mathrm{G}_{6}$ are treatments of guava terminal cuttings with IBA in powder form. 
Table.5 Effect of rooting media and IBA treatments on total leaf chlorophyll content $\left(\mathrm{mg} \mathrm{g}^{-1}\right)$ fresh weight of terminal cuttings in guava cv. Taiwan Pink at 135 DAP

\begin{tabular}{|c|c|c|c|c|}
\hline \multirow{3}{*}{$\begin{array}{c}\text { IBA } \\
\text { treatments } \\
(\mathbf{G})\end{array}$} & \multicolumn{3}{|c|}{$\begin{array}{c}\text { Total leaf chlorophyll content ( } \mathrm{mg} \mathrm{g}^{-1} \text { fresh } \\
\text { weight) }\end{array}$} & \multirow[t]{3}{*}{ Mean } \\
\hline & \multicolumn{3}{|c|}{ Rooting media (M) } & \\
\hline & $\begin{array}{l}\text { Coco peat } \\
\left(\mathrm{M}_{1}\right)\end{array}$ & $\begin{array}{l}\text { Vermiculite } \\
\qquad\left(\mathrm{M}_{2}\right)\end{array}$ & $\begin{array}{l}\text { Saw dust } \\
\left(\mathrm{M}_{3}\right)\end{array}$ & \\
\hline $250 \mathrm{ppm}\left(\mathrm{G}_{1}\right)$ & 1.98 & 1.70 & 1.59 & 1.75 \\
\hline $500 \mathrm{ppm}\left(\mathrm{G}_{2}\right)$ & 1.47 & 1.45 & 1.37 & 1.43 \\
\hline 750 ppm $\left(G_{3}\right)$ & 1.37 & 1.36 & 1.21 & 1.31 \\
\hline 1500 ppm $\left(G_{4}\right)$ & 2.10 & 1.84 & 1.79 & 1.91 \\
\hline 3000 ppm $\left(G_{5}\right)$ & 2.38 & 2.26 & 2.17 & 2.26 \\
\hline 6000 ppm $\left(G_{6}\right)$ & 2.21 & 1.95 & 1.87 & 2.00 \\
\hline Mean & 1.92 & 1.76 & 1.66 & 1.78 \\
\hline Factor & M & $\mathrm{G}$ & \multicolumn{2}{|c|}{$M \times G$} \\
\hline $\begin{array}{c}\text { S Em } \pm \\
\text { CD at } 5 \%\end{array}$ & $\begin{array}{l}0.014 \\
0.042\end{array}$ & $\begin{array}{l}0.020 \\
0.059\end{array}$ & \multicolumn{2}{|c|}{$\begin{array}{l}0.034 \\
0.102\end{array}$} \\
\hline
\end{tabular}

$\mathrm{G}_{1}, \mathrm{G}_{2}$ and $\mathrm{G}_{3}$ are treatments of guava terminal cuttings with IBA in solution form. $\mathrm{G}_{4}, \mathrm{G}_{5}$ and $\mathrm{G}_{6}$ are treatments of guava terminal cuttings with IBA in powder form.

Table.6 Effect of rooting media and IBA treatments on survival percentage of rooted Cuttings (\%) of terminal cuttings in guava cv. Taiwan Pink at 135 DAP

\begin{tabular}{|c|c|c|c|c|}
\hline \multirow{3}{*}{$\begin{array}{c}\text { IBA } \\
\text { treatments } \\
(\mathbf{G})\end{array}$} & \multicolumn{3}{|c|}{ Survival percentage of rooted cuttings ( $\%)$} & \multirow[t]{3}{*}{ Mean } \\
\hline & \multicolumn{3}{|c|}{ Rooting media (M) } & \\
\hline & Coco peat $\left(M_{1}\right)$ & $\begin{array}{c}\text { Vermiculite } \\
\qquad\left(\mathbf{M}_{2}\right)\end{array}$ & $\begin{array}{c}\text { Saw dust } \\
\left(\mathbf{M}_{3}\right)\end{array}$ & \\
\hline $250 \mathrm{ppm}\left(\mathrm{G}_{1}\right)$ & $66.00(54.32)$ & $60.00(50.75)$ & $60.00(50.75)$ & $62.00(51.94)$ \\
\hline 500 ppm $\left(G_{2}\right)$ & $62.00(51.92)$ & $57.00(49.00)$ & $59.00(50.17)$ & $59.33(50.36)$ \\
\hline $750 \mathrm{ppm}\left(\mathbf{G}_{3}\right)$ & $58.00(49.58)$ & $54.00(47.27)$ & $52.00(46.13)$ & $54.67(47.66)$ \\
\hline $1500 \mathrm{ppm}\left(\mathrm{G}_{4}\right)$ & $71.00(57.40)$ & $65.00(53.71)$ & $63.00(52.52)$ & $66.33(54.54)$ \\
\hline 3000 ppm $\left(G_{5}\right)$ & $79.00(62.71)$ & $75.00(59.98)$ & $69.00(56.15)$ & $74.33(59.61)$ \\
\hline 6000 ppm $\left(G_{6}\right)$ & $74.00(59.32)$ & $70.00(56.77)$ & $67.00(54.92)$ & $70.33(57.00)$ \\
\hline Mean & $68.33(55.87)$ & $63.50(52.91)$ & 61.67(51.77) & $64.50(53.52)$ \\
\hline Factor & M & G & \multicolumn{2}{|c|}{$M \times G$} \\
\hline $\begin{array}{c}\text { S Em } \pm \\
\text { CD at } 5 \%\end{array}$ & $\begin{array}{l}0.24 \\
0.72\end{array}$ & $\begin{array}{l}0.34 \\
1.01\end{array}$ & \multicolumn{2}{|c|}{$\begin{array}{l}0.59 \\
1.76\end{array}$} \\
\hline
\end{tabular}

$\mathrm{G}_{1}, \mathrm{G}_{2}$ and $\mathrm{G}_{3}$ are treatments of guava terminal cuttings with IBA in solution form.

$\mathrm{G}_{4}, \mathrm{G}_{5}$ and $\mathrm{G}_{6}$ are treatments of guava terminal cuttings with IBA in powder form.

*Figures in parenthesis indicate transformed values. 
IBA at $4000 \mathrm{ppm}$ produced healthier, lengthy roots which might have helped in the absorption of water and nutrients. Better nutrient absorption could have encouraged production of more number of leaves by the cuttings. The increase in number of leaves with IBA $4000 \mathrm{ppm}$ might be due to more number of roots, plant height and branches per cutting (Ismail and Asghar, 2007). The above results are in accordance with by Wahab et al., (2001), Malik et al., (2013) in guava. Similar results were reported by Riaz et al., (2007) in hardwood cuttings of kiwi.

\section{Leaf area per cutting $\left(\mathrm{cm}^{2}\right)$}

In the present investigation, rooting media, IBA treatments as well as their interactions were found to have significantly influenced the leaf area per cutting (Table 4).

The terminal cuttings planted in the coco peat showed significantly maximum leaf area per cutting $\left(193.66 \mathrm{~cm}^{2}\right)$ at 135 DAP and followed by those terminal cuttings planted in vermiculite medium $\left(167.61 \mathrm{~cm}^{2}\right)$, significantly minimum $\left(132.52 \mathrm{~cm}^{2}\right)$ leaf area per cutting was recorded by the terminal cuttings planted in saw dust.

Among the IBA treatments, the highest leaf area per cutting $\left(203.24 \mathrm{~cm}^{2}\right)$ was noticed in the terminal cuttings treated with IBA powder @ 3000 ppm followed by $\left(188.05 \mathrm{~cm}^{2}\right)$ terminal cuttings treated with IBA powder @ $6000 \mathrm{ppm}$, while the lowest leaf area per cutting $\left(130.65 \mathrm{~cm}^{2}\right)$ was observed with solution dip of IBA @ 750 ppm.

There existed a significant interaction between rooting media and IBA treatments for leaf area per cutting. Significantly maximum leaf area per cutting $\left(241.08 \mathrm{~cm}^{2}\right)$ was found in terminal cuttings planted in coco peat medium + treatment with IBA powder @ 3000 ppm $\left(\mathrm{M}_{1} \mathrm{G}_{5}\right)$.
The highest leaf area was recorded in terminal cuttings planted in coco peat which might be attributed to the better aeration, drainage conditions and moisture retentive capability (Khayyat et al., 2007). The cuttings treated with IBA powder@ 3000 ppm recorded the highest leaf area than the cuttings treated with IBA powder @ 6000 ppm. Production of high number of roots and also shoots as well sustaining them over a period of time between 45 and 135 days after planting of cutting is indicative for the fact that the energy metabolism in the cells would have been active in such cuttings. Nutrient uptake with healthy and strong root system could have boosted the rate of photosynthesis gaining much stronger position to nurture the growing leaves and expanding them leading to a maximum leaf area per cutting (Ismail and Asghar, 2007). These results are in line with Ismail and Asghar (2007) and Sukhjit (2015) in hardwood cuttings of peach.

\section{Total leaf chlorophyll content ( $\mathrm{mg} \mathrm{g}^{-1}$ fresh weight)}

The total leaf chlorophyll content varied significantly by the influence of rooting media, IBA treatments as well as their interactions. It was observed that the maximum total leaf chlorophyll content per cutting at 135 DAP was recorded in terminal cuttings planted in coco peat medium (1.92 $\mathrm{mg} \mathrm{g}^{-1}$ fresh weight) followed by those planted in the vermiculite $\left(1.76 \mathrm{mg} \mathrm{g}^{-1}\right.$ fresh weight) and minimum total leaf chlorophyll content (1.66 $\mathrm{mg} \mathrm{g}^{-1}$ fresh weight) was recorded in terminal cuttings planted in saw dust (Table 5).

Among IBA treatments, the highest total leaf chlorophyll content (2.26 $\mathrm{mg} \mathrm{g}^{-1}$ fresh weight) was noticed in terminal cuttings treated with IBA powder @ 3000 ppm followed (2.00 mg $\mathrm{g}^{-1}$ fresh weight) by those treated with IBA powder@6000 ppm and the lowest total leaf 
chlorophyll content was observed in terminal cuttings of IBA solution dip @ 750 ppm (1.31 $\mathrm{mg} \mathrm{g}^{-1}$ fresh weight).

There existed a significant interaction between rooting media and IBA treatments for maximum total leaf chlorophyll content. Significantly maximum total leaf chlorophyll content (2.38 $\mathrm{mg} \mathrm{g}^{-1}$ fresh weight) was found in terminal cuttings planted in coco peat medium + treatment with IBA powder @ 3000 ppm $\left(\mathrm{M}_{1} \mathrm{G}_{5}\right)$.

The terminal cuttings treated with IBA powder@ 3000 ppm recorded maximum total leaf chlorophyll content than others. The increased leaf area with increased concentrations of auxins might have activated the process of photosynthesis resulting in more chlorophyll content of leaves per cutting. Growth hormones have been shown to play an important role in regulating the amount and distribution of assimilates in plants (Galston and Davies, 1969). Ratnakumari (2014) observed that cuttings with more number of leaves enhanced nutrients uptake thereby increased the photosynthates production and provided sufficient food contents for the metabolic activities of the plants by means of mounting the levels of light harvesting pigments especially chlorophylls. Similar results were reported by Kaur et al., (2002) in grapes; Sivaci and Yalcin (2006) in apple. These results are in line with Oscar and Javier (2014) in cape gooseberry.

\section{Survival percentage of rooted cuttings (\%)}

There were significant differences in respect of survival percentage of rooted terminal cuttings among the different rooting media and IBA treatments as well as their interactions at 135 DAP, the terminal cuttings planted in coco peat medium were found to have maximum survival percentage of rooted cuttings $(68.33 \%)$ followed by those planted in vermiculite $(63.50 \%)$ whereas, the minimum survival percentage of terminal cuttings was noticed in saw dust (61.67\%).

Among IBA treatments, the highest survival percentage $(74.33 \%)$ was noticed in IBA powder dip @ 3000 ppm followed by (70.33\%) those treated terminal cuttings with IBA powder dip @ 6000 ppm and the minimum survival percentage of rooted terminal cuttings was noticed in solution dip of IBA@750ppm (54.67\%) (Table 6).

There existed a significant interaction between rooting media and IBA treatments with respect to survival percentage of rooted terminal cuttings. Significantly maximum survival percentage of rooted terminal cuttings $(79.00 \%)$ was found in terminal cuttings planted in coco peat medium + treatment with IBA powder dip @ 3000 ppm $\left(\mathrm{M}_{1} \mathrm{G}_{5}\right)$.

The cuttings planted in coco peat medium gave highest survival percentage might be due to its corresponding merit in root and shoot growth and sustenance over a period of time. The advantages with coco peat might be due to incorporation of coarser material which would improve the aeration status of medium (Awang et al., 2009). Aeration is necessary for the gaseous exchange between the soil and atmosphere to remove $\mathrm{CO}_{2}$ released by roots and microorganisms in the soil to external atmosphere and supply of $\mathrm{O}_{2}$ from the external atmosphere to the growing roots leading to better respiration and survival of plants (Jeyaseeli and Paul, 2010).

The highest survival percentage was recorded in the cuttings treated with IBA powder dip @ $3000 \mathrm{ppm}$, which might due to development of effective root system and increase in number and length of roots per cutting as influenced by the uptake of nutrients and 
water (Reddy et al., 2008). The survival of the sprouted cuttings might be directly linked to the formation of adventitious roots on cuttings.

Auxins role in inducing roots in the cuttings as described by many researchers is in consistency with the results of the study. The possible explanation to these findings lies in better development of root system with more number of roots, greater root length, fresh and dry weight of roots which would have enabled the rooted cuttings to survive till the end in the polybag thereby recording the highest survival (Goudappa, 2016). The above results are in accordance with Abdul et al., (2013) in guava, Abdullah et al., (2006) in guava Sukhjit (2015) in hardwood cuttings of peach. Riaz et al., (2007) reported the highest survival percentage in $3000 \mathrm{ppm}$ of IBA than $6000 \mathrm{ppm}$ of IBA in hardwood cuttings of kiwi.

\section{Acknowledgement}

This work was supported in part by the Dr. YSR. Horticultural University, Venkataramannagudem through stipend for financial support. Acknowledgment is also made to Mr. Maddipati Suryanarayana, Uma maheswari nursery supported a lot by providing planting material for the research work.

\section{References}

Abdul, K, Muhammad, J, Bilquees, F. and Bushra, S. 2013. Clonal multiplication of guava through softwood cuttings under mist conditions. Pakisthan Journal of Agricultural Sciences. 50(1): 23-27.

Abdullah, A.T.M, Hossain, M.A. and Bhuiyan, M.K. 2006. Clonal propagation of guava (Psidium guajava L.) by stem cutting from mature stockplants. Journal of Forestry Research. 17(4): 301-04.

Abraham, A.J. 1996. Studies on propagation of carnation (Dianthus carophyllus L.) by stem cuttings under mist. M.Sc. thesis. University of Agricultural Sciences, Dharwad.

Awang, Y, Shaharom, A. Sh, Mohamad, R.B. and Selamat, A. 2009. Chemical and physical characteristics of coco peat based media mixtures and their effects on growth and development of Celosia cristata. American Journal of Agricultural and Biological Science. 4: 63-71.

Galston A.W. and Davies P.J. 1969. Hormonal regulation in higher plants. Science. 163: 1288-97.

Giri, C, Shyamkumar, B, and Anjaneyulu, C. 2004. Progress in tissue culture, genetic transformation and applications of biotechnology to trees. Trees, 18: 11535.

Goudappa, T.P. 2016. Studies on rhizogenesis in West Indian cherry (Malphigia puncifolia L.). M.Sc. Thesis. Dr. Y.S.R. Horticultural University, Venkataramannagudem.

Gupta, M.R. and Malhotra, N.K. 1985. Propagation studies in guava (Psidium guajava L.) cv. Allahabad Safeda. Journal of Research. PAU, Ludhiana. 22: 267-69.

Habibi, K.S. 2010. Effect of Auxin different concentrations on rooting of the semihardwood cutting in oleander plant. Journal on Plant Science Researchers. 18(2): 36-46.

Ismail, S.M. and Asghar, H.I. 2007. Effect of indole butyric acid and types of cuttings on root initiation of Ficus hawaii. Sarhad Journal of Agriculture. 23(4): 919-25.

Jaiswal, V.S. and Nasim, A. 1992. Somatic embryogenesis and plantlet regeneration from zygotic embryos of (Psidium 
guajava L.). In: Proceeding of I.S.H.S. Symposium, Maryland, USA (Abstract). Jeyaseeli, D.M. and Paul Raj, S. 2010. Chemical characteristics of coir pith as a function of its particle size to be used as soilless medium. An International Quarterly Journal of Environmental Sciences. 4(2\&3): 163-69.

Kaur, S, Cheema, S.S, Chhabra, B.R. and Talwar, K.K. 2002. Chemical induction of physiological changes during adventitious root formation and bud break in grapevine cuttings. Plant Growth Regulation. 37: 63-68.

Khayyat, M, Nazari, F. and Salehi, H. 2007. Effects of different pot mixtures on pothos (Epipremnum aureum Lindl. and Andre 'Golden Pothos') growth and development. Am-Euras. Journal of Agriculture and Environmental Sciences. 2: 341-48.

Krieken, W.M, Breteler, H. Visser, M.H.M. and Mavridou, D. 1993. The role of the conversion of IBA into IAA on root regeneration in apple: Introduction of a test system. Plant Cell Reports. 12: 203 06.

Lokesha, R, Mahishi, D.M. and Shivashankar, G. 1988. Studies on the use of coconut coir dust as a rooting media. Current Research. 17(12): 157-158.

Malik, M.A, Muhammad, K.R, Muhammad, A.J, Saeed, A, Sitwat, R. and Javaid, I. 2013. Production of true-to-type guava nursery plants via application of IBA on soft wood cuttings. Journal of Agricultural Research. 51(3): 1-8.

Manna, A, Mathew, B. and Ghosh, S.N. 2004. Air layering in guava cultivars. Journal of Inleracademicia, Nadia India. 2: 27881.

Mayer, N.A, Reighard, G.L. and Bridges, W. 2015. Peach Rootstock Propagation under Intermittent Mist System. Acta horticulturae. Proceedings VIII
International Peach Symposium. Pages: 53-63.

Melgarejo, P. Martinez, J. Amoros, A. Martinez, R. 2000. Study of the rooting capacity of ten pomegranate clones (Punica granatum L.). Options Mediterraneennes. Serie A, Seminaires Mediterraneens. (42): 163-67.

Mukherjee, S.K. and Majumdar, P.K. 1983. Vegetative propagation of tropical and sub-tropical fruit crops. ICAR, New Delhi.

Nagarajan, R, Manickam, T.S. and Kothandaraman, G.V. 1985. Manurial value of coir pith. Madras Agricultural Journal. 72: 533-35.

NHB, 2015. Indian Horticulture Database, 2014-15. National Horticulture Board, New Delhi. www.nhb.gov.in.

Oscar, H.A.S. and Javier, G.A.H. 2014. Effect of Indole-3-Butyric Acid and Trichoderma harzionum Rifai on asexual cape gooseberry propagation (Physalis peruviana L.). Agronomía Colombiana. 32(3): 326-33.

Pathak, R.K. and Saroj, P.L. 1988. Studies on the propagation of guava species by stool layering. Fruit Research Workshop, Subtropical and Temperate Fruits, Rajendra Agricultural University, Pusa, Bihar.

Paul, R. and Aditi, C.H. 2009. IBA and NAA of $1000 \mathrm{ppm}$ induce more improved rooting characters in air-layers of waterapple (Syzygium javanica L). Bulgarian Journal of Agricultural Science. 15(2): 123-28.

Purseglove, J.W. 1977. Tropical dicotlydons. $1 \& 2$ combined. 417-18.

Rathore, D.S. 2001. Guava. In: Handbook of Horticulture. Indian Council of Agricultural Research, New Delhi.

Ratnakumari. 2014. Effect of rooting media on rhizogenesis of pomegranate (Punica granatam L.) cv. Baghwa. M.Sc. Thesis. 
Dr. Y.S.R. Horticultural University, Venkataramannagudem.

Reddy, R. K.V, Pulla R.Ch. and Goud, P.V. 2008. Effect of auxins on the rooting of fig (Ficus carica L.) hardwood and semi hardwood cuttings. Indian Journal of Agricultural Research. 42(1): 75 78.

Riaz A, Khalil U.R, Muhammad I, Muhammad I. and Muhammad A.R. 2007. Effect of indole butyric acid concentrations on the rooting of kiwi cuttings. Sarhad Journal of Agriculture. 23: 293-95.

Shadparvar, V, Mohammadi, T. and Alinejad, A.A.H. 2011. Effect of IBA and Soil mixture on rooting of (Hibiscus rosasinensis). European Journal of Experimental Biology. 1(4): 142-46.

Singh, G, Gupta, S, Mishra, R. and Singh, G.P. 2005. Wedge grafting in guava- A Novel vegetative propagation technique. Central Institute for Subtropical Horticulture, Lucknow, 12.

Singh, G, Singh, A.K. and Verma, A. 2000. Economic evaluation of crop regulation treatments in guava (Psidium guajava L.). Indian Journal of Agriculture Sciences. 70: 226-30.
Sivaci, A. and Yalcin, I. 2006. Determination of physiological changes in related to effects of exogenous Indole-ButyricAcid and callus formation in some kinds of Apple (Malus sylvestris Miller) stem cuttings. Fen Bilimleri Dergisi. 27(2): $1-12$.

Smith, Ch. 1995. Coir: a viable alternative to peat for potting. The Horticulturist. 4(3): $12-25$.

Sukhjit, K. 2015. Effect of different treatments of Indole-3-butyric acid (IBA) on the rooting and growth performance of hardwood cuttings of Peach (Prunus persica L.). Agricultural Science Digest. 35(1): 41-45.

Thayamini, H, Seran, A. and Thiresh. 2015. Root and shoot growth of dragon fruit (Hylocereus undatus) stem cutting as influenced by Indole Butyric Acid. Agricultural and Biological Sciences Journal. 1: 27-30.

Wahab, F, Nabi, G, Ali, N. and Shah, M. 2001. Rooting response of semi hard wood cuttings of guava (Psidium guajava L.) to various concentrations of different auxins. Online Journal of Biological Sciences. 1(4): 184-87.

\section{How to cite this article:}

Dhatrika Rani, T., D. Srihari, A.V.D. Dorajeerao and Subbaramamma, P. 2018. Effect of Rooting Media and IBA Treatments on Shoot Production and Survival of Terminal Cuttings in Guava (Psidium guajava L.) cv. Taiwan Pink. Int.J.Curr.Microbiol.App.Sci. 7(11): 231-242. doi: https://doi.org/10.20546/ijcmas.2018.711.029 